\title{
24. ISOTOPIC COMPOSITION OF OXYGEN, CARBON, AND SULFUR IN INTERSTITIAL WATER AND CORES FROM DEEP SEA DRILLING PROJECT LEG 59
}

\author{
A. A. Migdisov, V. M. Belyi, V. A. Grinenko, Yu. P. Girin, M. A. Kiselevsky, and G. S. Zakariadze, V. I. Vernadsky \\ Institute of Geochemistry and Analytical Chemistry, U.S.S.R. Academy of Sciences, Moscow 117334, U.S.S.R.
}

\section{INTRODUCTION}

Comprehensive isotopic studies based on data from the Deep Sea Drilling Project have elucidated numerous details of the low- and high-temperature mechanisms of interaction between water and rocks of ocean crustal seismic Layers 1 and 2 . These isotopic studies have also identified climatic changes during the Meso-Cenozoic history of oceans. Data on the abundance and isotopic composition of sulfur in the sedimentary layer as well as in rocks of the volcanic basement are more fragmentary than are oxygen and carbon data.

In this chapter we specifically concentrate upon isotopic data related to specific features of the mechanisms of low-temperature interaction of water with sedimentary and volcanogenic rocks. The Leg 59 data provide a good opportunity for such lithologic and isotopic studies, because almost 600 meters of basalt flows and sills interbedded with tuffs and volcaniclastic breccias were cored during the drilling of Hole 448A. Moreover, rocks supposedly exposed to hydrothermal alteration play an important role at the deepest horizons of that mass. Sulfur isotopic studies of the character of possible biogenic processes of sulfate reduction in sediments are another focus, as well as the nature and origin of sulfide mineralization in Layer-2 rocks of remnant island arcs. Finally, oxygen and carbon istopic analyses of biogenic carbonates in the cores also enabled us to investigate the effects of changing climatic conditions during the Cenozoic. These results are compared with previous data from adjacent regions of the Pacific Ocean.

Thus this chapter describes results of isotopic analyses of: oxygen and sulfur of interstitial water; oxygen and carbon of sedimentary carbonates and of calcite intercalations and inclusions in tuffs and volcaniclastic breccias interbedded with basalt flows; and sulfur of sulfides in these rocks.

\section{EXPERIMENTAL PROCEDURE}

The preliminary processing of carbonates for oxygen and carbon isotope analyses consisted of grinding dry samples and heating them in a vacuum at $450^{\circ} \mathrm{C}$ for half an hour. Then samples were treated with $100 \%$ orthophosphoric acid at $25^{\circ} \mathrm{C}$. The $\mathrm{CO}_{2}$ obtained by this treatment was analyzed using a Varian-Mat 230 mass spectrometer. The results of carbon isotopic analyses are expressed as per mil relative to the PDB standard, and $\delta^{18} \mathrm{O}$ data are expressed as per mil relative to the SMOW standard. Error does not exceed $0.1 \%$ for isotopic analyses.

Sulfur was isolated from interstitial water as $\mathrm{BaSO}_{4}$ and, in its pyrite and monosulfide forms, from sediments and rocks by the method suggested by Volkov and Zhabina (1977). Isotopic analysis of $\mathrm{SO}_{2}$ was performed by means of the MI-1305 mass spectrometer following the procedure suggested by Ustinov and Grinenko (1965). The experimental error was $0.3 \% ; \delta^{34} \mathrm{~S}$ data are expressed as per mil relative to the meteorite standard.

The determination of the isotopic composition of oxygen in interstitial water required its pre-equilibration with $\mathrm{CO}_{2}$ (Teys and Naydin, 1973); the latter then was analyzed using the MI-1305 mass spectrometer with an error of $0.3 \%$. The $\delta^{18} \mathrm{O}$ values for oxygen are expressed as per mil relative to SMOW.

\section{RESULTS}

Isotopic analyses of all the samples examined are summarized in Tables 1 and 2 . Isotopic variations and some correlative dependencies are shown in Figures 1 through 6.

Interstitial water oxygen shows variations of isotopic composition for portions of Holes 447A through 451, with $\delta^{18} \mathrm{O}$ values ranging from $0.5 \%$ to $-1.6 \%$ (Table 1, Figs. 1-3). Most samples are poor in heavy isotope relative to the seawater standard. $\delta^{18} \mathrm{O}$ values of interstitial water range from $-0.5 \%_{0}-1.1 \%$ in the first meters of the sedimentary column. In deeper parts of the studied sections, which are mainly formed of pelagic red clays or carbonates, interstitial water oxygen was found to be richer in the ${ }^{18} \mathrm{O}$ isotope as the depth of the sedimentary layer increased up to 50 to 100 meters. The heaviest oxygen, which was $1.3 \%$ greater than that of the high horizons, was found in carbonate nannofossil ooze in Hole 448 at a depth of 47 meters. In pelagic clays in Holes 449 and 450 , the values of ${ }^{18} \mathrm{O}$ at depth are somewhat less: $0.9 \%$ greater than surface values at a sub-bottom depth of about 100 meters. A maximum value of only $0.5 \%$ was found in the foraminifer ooze and carbonate tuff in Hole 451.

The isotopic composition of interstitial water from the deeply cored volcaniclastic breccias and tuffs also appears to be poorer in ${ }^{18} \mathrm{O}$ than the nannofossil oozes. Consequently, water of volcanogenic clastic parts of the section is richer in light oxygen isotope than that of the clay-carbonate part. These changes can be most distinctly observed in Hole 450 , beginning at the 90 -meter sub-bottom depth, where a uniform andesitic-tuff composition occurs. In this case, the ${ }^{18} \mathrm{O}$ contents average only $-1.1 \%$ relative to standard seawater. The highest value of interstitial water isotopic composition in the tuff occurs at 90 to 100 meters sub-bottom. The isotopic composition of interstitial water oxygen below 200 meters sub-bottom remains practically constant. It is a remarkable fact that variations of the chemical composition of interstitial water within the tuffaceous part of Hole 450 have similar features (Fig. 2). 
Table 1. Oxygen, sulfur, and carbon isotopic composition of pore water and of cores in Leg 59 holes.

\begin{tabular}{|c|c|c|c|c|c|c|c|c|c|c|}
\hline \multirow{2}{*}{$\begin{array}{l}\text { Sample } \\
\text { (interval } \\
\text { in } \mathrm{cm} \text { ) }\end{array}$} & \multirow{2}{*}{$\begin{array}{l}\text { Depth } \\
\text { in Hole } \\
\text { (m) }\end{array}$} & \multirow{2}{*}{ Lithologic Description } & \multirow{2}{*}{ 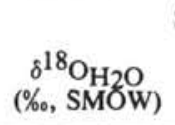 } & \multicolumn{2}{|c|}{ Sulfate-Ion Derived } & \multirow[b]{2}{*}{$\begin{array}{l}\mathrm{CO}_{2} \\
(\%)\end{array}$} & \multicolumn{2}{|c|}{ Carbonate Derived } & \multirow[b]{2}{*}{$\begin{array}{l}\text { Pyrite } \\
(\%)\end{array}$} & \multirow{2}{*}{ 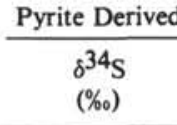 } \\
\hline & & & & $\begin{array}{l}\delta^{34} S \\
(\%)\end{array}$ & $\begin{array}{l}\mathrm{SO}_{4} \\
(\%)\end{array}$ & & $\begin{array}{c}\delta^{13} \mathrm{C} \\
(\%, \mathrm{PDB})\end{array}$ & $\begin{array}{c}\delta^{18} \mathrm{O} \\
(\%, \text { SMOW })\end{array}$ & & \\
\hline $\begin{array}{l}451-2-4 \\
140-150\end{array}$ & 11.0 & $\begin{array}{l}\text { foraminifer-nanno- } \\
\text { fossil ooze }\end{array}$ & -0.5 & 20.4 & 0.103 & 29.36 & 0.0 & 29.9 & $<0.001$ & - \\
\hline $\begin{array}{l}451-5-3 \\
140-150\end{array}$ & 38.0 & $\begin{array}{l}\text { carbonate-bearing } \\
\text { vitric tuff }\end{array}$ & -0.1 & 19.9 & 0.096 & 6.56 & 0.7 & 29.7 & $<0.001$ & - \\
\hline $\begin{array}{l}451-14-1 \\
140-150\end{array}$ & 120.5 & " & 0.0 & 20.5 & 0.090 & 4.97 & 0.4 & 30.0 & 0.017 & -5.8 \\
\hline $\begin{array}{l}451-34-1 \\
140-150\end{array}$ & 310.5 & vitric tuff & - & 10.8 & $0.217^{\mathrm{a}}$ & 0.58 & -2.3 & 12.1 & 0.312 & -2.7 \\
\hline $\begin{array}{l}451-54-2 \\
0-8\end{array}$ & 480.0 & $\begin{array}{l}\text { vitric tuff with basaltic } \\
\text { clasts and calcite veins }\end{array}$ & - & - & - & - & 0.8 & 28.5 & 0.005 & - \\
\hline $\begin{array}{l}450-1-4 \\
144-150\end{array}$ & 6.0 & pelagic clay & -1.1 & 19.3 & 0.082 & 0.51 & - & - & $<0.001$ & - \\
\hline $\begin{array}{l}450-5-2 \\
144-150\end{array}$ & 39.0 & $\begin{array}{l}\text { ash-bearing } \\
\text { pelagic clay }\end{array}$ & -0.5 & 19.4 & 0.104 & $<0.01$ & - & - & $<0.001$ & - \\
\hline $\begin{array}{l}450-12-2 \\
140-150\end{array}$ & 105.4 & vitric tuff & -0.2 & 19.1 & 0.091 & 0.64 & - & - & $<0.001$ & - \\
\hline $\begin{array}{l}450-16-3, \\
140-150\end{array}$ & 145.0 & " & -0.5 & 20.4 & 0.096 & 0.05 & - & - & $<0.001$ & - \\
\hline $\begin{array}{l}450-20-1 \\
140-150\end{array}$ & 180.0 & $"$ & -1.6 & 18.4 & 0.100 & 0.69 & - & - & 0.003 & - \\
\hline $\begin{array}{l}450-24-3 \\
140-150\end{array}$ & 221.0 & 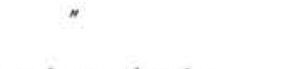 & -1.4 & 19.7 & 0.092 & 0.36 & - & - & 0.003 & - \\
\hline $\begin{array}{l}450-28-4 \\
140-150\end{array}$ & 260.5 & $\begin{array}{l}\text { carbonate-bearing } \\
\text { vitric tuff }\end{array}$ & -1.5 & 19.5 & 0.090 & 2.62 & 1.0 & 29.6 & $<0.001$ & - \\
\hline $\begin{array}{l}450-32-3 \\
140-150\end{array}$ & 306.5 & " & -1.5 & 20.7 & 0.091 & 3.34 & 1.9 & 29.3 & $<0.001$ & - \\
\hline $\begin{array}{l}449-2-2 \\
140-150\end{array}$ & 3.0 & pelagic clay & -0.7 & 19.3 & 0.090 & 0.40 & - & - & - & - \\
\hline $\begin{array}{l}449-5-1 \\
140-150\end{array}$ & 30.0 & " & -0.3 & 20.1 & 0.089 & 0.19 & - & - & - & - \\
\hline $\begin{array}{l}449-7-5 \\
24-29\end{array}$ & 55.0 & $\begin{array}{l}\text { clay-bearing nanno- } \\
\text { fossil ooze }\end{array}$ & - & - & - & 22.22 & 1.8 & 30.0 & - & - \\
\hline $\begin{array}{l}449-8-4 \\
140-150\end{array}$ & 63.0 & pelagic clay & -0.1 & 20.1 & 0.092 & 1.17 & - & - & - & - \\
\hline $\begin{array}{l}449-11-4 \\
140-150\end{array}$ & 91.0 & pelagic clay & 0.2 & 19.4 & 0.092 & 0.30 & - & - & - & - \\
\hline $\begin{array}{l}449-12-2 \\
102-104\end{array}$ & 98.0 & nannofossil ooze & - & 19.7 & $0.092^{\mathrm{a}}$ & 28.26 & 2.2 & 31.2 & $<0.001$ & - \\
\hline $\begin{array}{l}448-1-2 \\
113-128\end{array}$ & 2.7 & " & -0.8 & 19.7 & 0.081 & 32.78 & 0.9 & 31.6 & $<0.001$ & - \\
\hline $\begin{array}{l}448-6-3 \\
140-150\end{array}$ & 47.5 & $"$ & 0.5 & - & 0.103 & 21.30 & 1.5 & 31.5 & 0.004 & - \\
\hline $\begin{array}{l}448-11-1 \\
47-49\end{array}$ & 91.5 & " & - & - & - & 34.56 & 1.6 & 31.8 & $<0.001$ & - \\
\hline $\begin{array}{l}448-11-4 \\
140-150\end{array}$ & 96.5 & 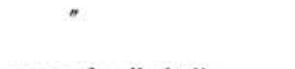 & 0.1 & 19.9 & 0.082 & - & - & - & - & - \\
\hline $\begin{array}{l}448-13-4 \\
119-121\end{array}$ & 115.5 & nannofossil chalk & - & - & - & 36.54 & 1.1 & 31.9 & $<0.001$ & - \\
\hline $\begin{array}{l}\text { 448-14-3, } \\
9-11\end{array}$ & 123.5 & " & - & 19.2 & $0.115^{\mathrm{a}}$ & 38.89 & 1.3 & 31.2 & $<0.001$ & - \\
\hline $\begin{array}{l}448-16-5 \\
140-150\end{array}$ & 145.5 & 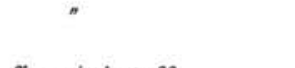 & 0.0 & 19.8 & 0.089 & 35.57 & 1.2 & 31.6 & - & - \\
\hline $\begin{array}{l}448-17-5 \\
22-24\end{array}$ & 153.5 & fine vitric tuff & - & - & - & 1.03 & 7.3 & 33.1 & - & - \\
\hline $\begin{array}{l}448-21-3 \\
135-150\end{array}$ & 190.0 & " & -0.7 & 19.4 & 0.090 & $<0.01$ & - & - & $<0.001$ & - \\
\hline $\begin{array}{l}448-26-2 \\
141-160\end{array}$ & 235.9 & fine vitric tuff & -0.4 & 19.5 & 0.088 & 0.04 & - & - & 0.120 & -5.4 \\
\hline $\begin{array}{l}448-29-1 \\
30-32\end{array}$ & 263.0 & $\begin{array}{l}\text { carbonate-rich } \\
\text { vitric tuff }\end{array}$ & - & - & - & 19.60 & 1.6 & 29.7 & 0.006 & - \\
\hline $\begin{array}{l}448-31-1 \\
87-90\end{array}$ & 282.0 & $\begin{array}{l}\text { ash-bearing nanno- } \\
\text { fossil chalk }\end{array}$ & - & - & - & 22.94 & 1.3 & 30.8 & $<0.001$ & - \\
\hline $\begin{array}{l}448-34-1 \\
38-40\end{array}$ & 310.0 & $\begin{array}{l}\text { carbonate-bearing } \\
\text { vitric tuff }\end{array}$ & - & - & - & 6.22 & -1.8 & 31.5 & - & - \\
\hline $\begin{array}{l}448-34-2 \\
71-73\end{array}$ & 311.5 & volcaniclastic breccia & - & 18.2 & $0.092^{\mathrm{a}}$ & - & - & - & $<0.001$ & - \\
\hline
\end{tabular}


Table 1. (Continued).

\begin{tabular}{|c|c|c|c|c|c|c|c|c|c|c|}
\hline \multirow{2}{*}{$\begin{array}{l}\text { Sample } \\
\text { (interval } \\
\text { in } \mathrm{cm} \text { ) }\end{array}$} & \multirow{2}{*}{$\begin{array}{l}\text { Depth } \\
\text { in Hole } \\
(\mathrm{m})\end{array}$} & \multirow{2}{*}{ Lithologic Description } & \multirow{2}{*}{$\begin{array}{c}\delta^{18} \mathrm{O}_{\mathrm{H}} \mathrm{O} \\
(\%, \mathrm{SMOW})\end{array}$} & \multicolumn{2}{|c|}{ ulfate-Ion Derived } & \multirow[b]{2}{*}{$\begin{array}{l}\mathrm{CO}_{2} \\
(\%)\end{array}$} & \multicolumn{2}{|c|}{ Carbonate Derived } & \multirow[b]{2}{*}{$\begin{array}{c}\text { Pyrite } \\
(\%)\end{array}$} & \multirow{2}{*}{$\begin{array}{c}\text { Pyrite Derived } \\
\delta^{34} \mathrm{~S} \\
\left(\%_{0}\right)\end{array}$} \\
\hline & & & & $\begin{array}{l}\delta^{34} \mathrm{~S} \\
(\%)\end{array}$ & $\begin{array}{l}\mathrm{SO}_{4} \\
(\%)\end{array}$ & & $\begin{array}{c}{ }^{\delta^{13} \mathrm{C}} \\
(\%, \mathrm{PDB})\end{array}$ & $\begin{array}{c}\delta^{18} \mathrm{O} \\
(\%, \text { SMOW })\end{array}$ & & \\
\hline $\begin{array}{l}448 \mathrm{~A}-6-1 \\
140-150\end{array}$ & 253.5 & vitric tuff & -0.2 & - & - & 0.08 & - & - & 0.005 & - \\
\hline $\begin{array}{l}448 A-8-1 \\
57-60\end{array}$ & 272.0 & nannofossil chalk & - & 20.3 & $0.148^{\mathrm{a}}$ & 25.25 & 1.4 & 31.7 & $<0.001$ & - \\
\hline $\begin{array}{l}\text { 447A-1-3, } \\
98-100\end{array}$ & 7.0 & pelagic clay & - & 19.7 & $0.137^{\mathrm{a}}$ & - & - & - & - & - \\
\hline $\begin{array}{l}447-4-3 \\
140-150\end{array}$ & 32.5 & 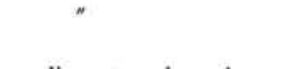 & - & 19.3 & $0.127^{\mathrm{a}}$ & - & - & - & $<0.001$ & - \\
\hline $\begin{array}{l}\text { 447A-5-2, } \\
97-99\end{array}$ & 40.5 & sedimentary breccia & - & - & - & 5.77 & 1.6 & 29.3 & - & - \\
\hline $\begin{array}{l}447 A-6-4, \\
63-65\end{array}$ & 52.0 & pelagic clay & - & 20.2 & $0.095^{\mathrm{a}}$ & - & - & - & - & - \\
\hline $\begin{array}{l}447 A-6-5 \\
140-150\end{array}$ & 54.5 & $"$ & -0.5 & 20.1 & 0.102 & 0.92 & - & - & $<0.001$ & - \\
\hline $\begin{array}{l}\text { 447A-7-4, } \\
77-79\end{array}$ & 61.5 & $\begin{array}{l}\text { volcanic glass-bearing } \\
\text { pelagic clay }\end{array}$ & - & 19.3 & $0.046^{\mathrm{a}}$ & - & - & - & 0.005 & - \\
\hline $\begin{array}{l}447 \mathrm{~A}-11-1 \\
11-15\end{array}$ & 94.5 & $\begin{array}{l}\text { basalt-derived } \\
\text { sedimentary breccia }\end{array}$ & - & 19.2 & $0.078^{\mathrm{a}}$ & - & - & - & 0.010 & - \\
\hline
\end{tabular}

a Sulfate was separated from rock samples with the use of hot distilled water.

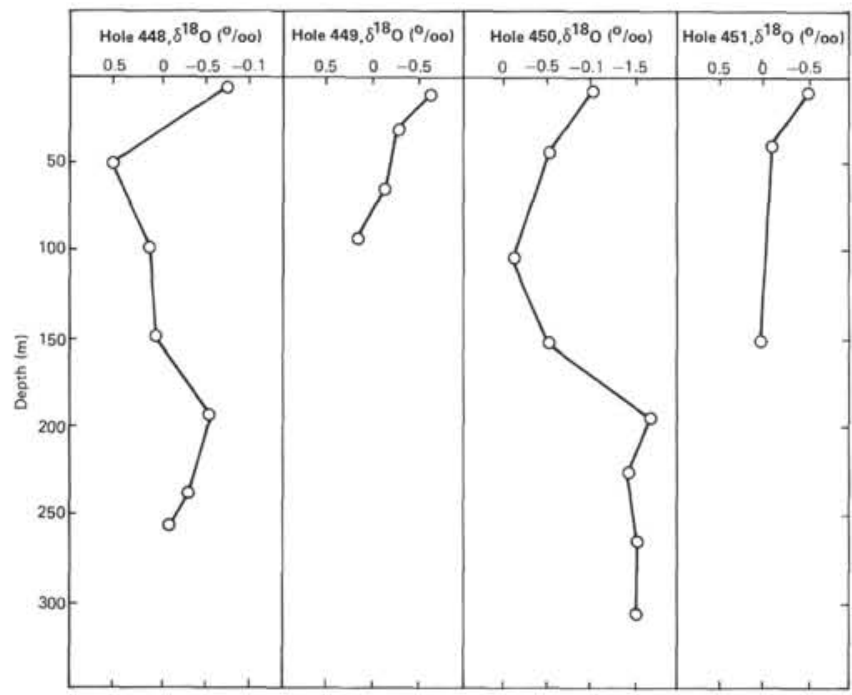

Figure 1. Variations of $\delta^{18} \mathrm{O}$ value of interstitial water in Holes 448 through 451 .

The sulfur isotopic composition of sulfate-ions in interstitial water analyzed from samples from all holes exhibits negligible fluctuations around the mean $\delta^{34} \mathrm{~S}$ value of $19.8 \%$, which corresponds to sulfur of sulfate in the ocean. The concentration of sulfate also fluctuates within the limits usual for ocean water (Table 1). In samples where sulfate was removed not from interstitial water extracted aboard ship but from rock samples (with the use of hot distilled water), its concentration was slightly higher in some cases. This slight increase in sulfate may have been the result of

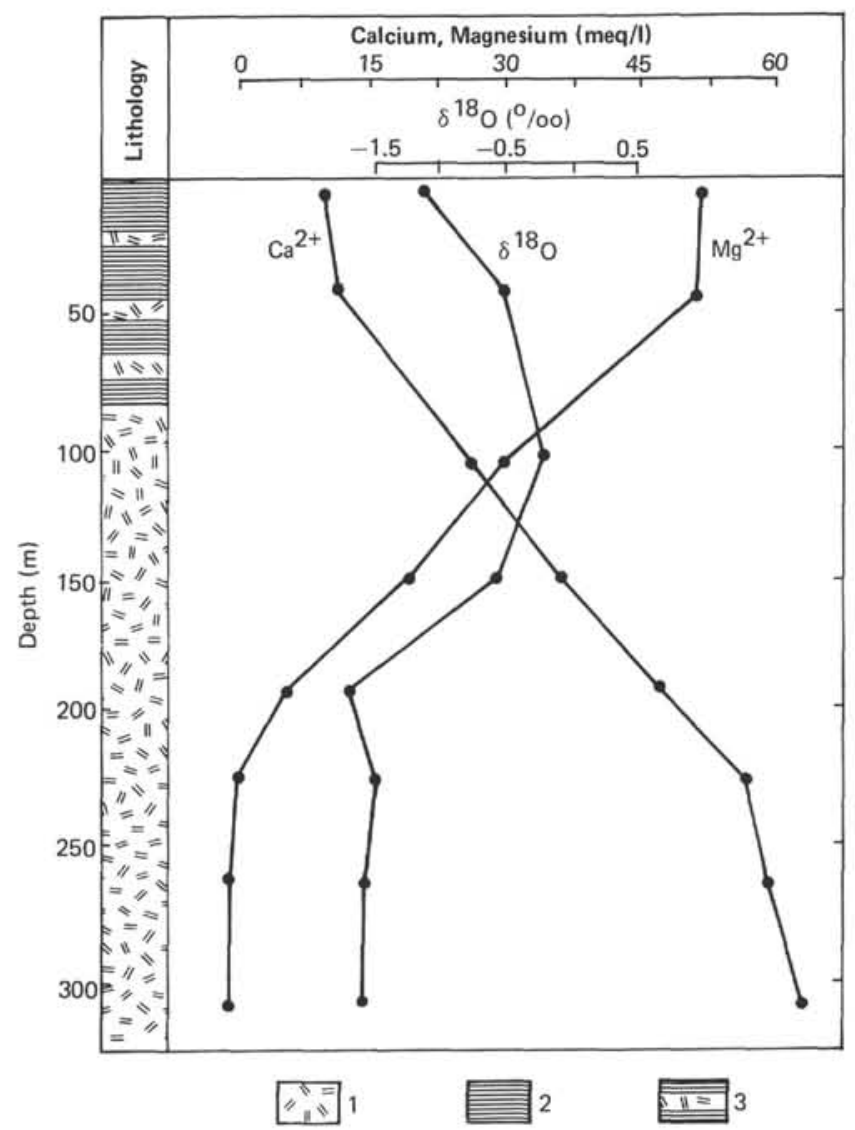

Figure 2. Variations in the calcium and magnesium content and $\delta^{18} \mathrm{O}$ of interstitial water in Hole 450 . $(1=$ volcanic tuff; $2=$ red pelagic clay; $3=$ pelagic clays with tuff intercalations.) 


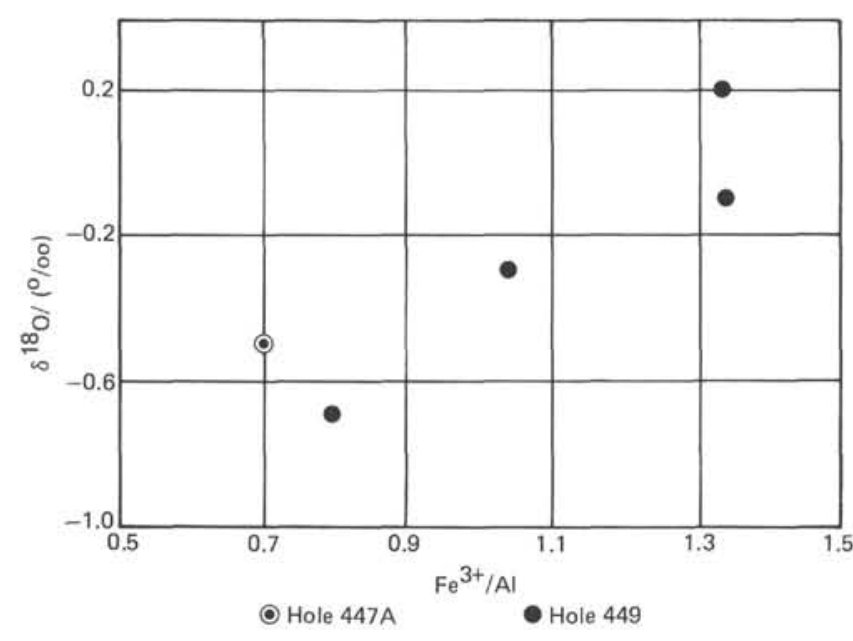

Figure 3. Variations of $\delta^{18} \mathrm{O}$ value of interstitial water and $\mathrm{Fe}^{3+} / \mathrm{Al}$ ratio in containing pelagic clays in Holes $447 \mathrm{~A}$ and 449.

moisture loss during its transportation. In one such sample (Sample 451-34-1, 140-150 cm), the $\delta^{34} \mathrm{~S}$ value was equal to $10.8 \%$, which is definitely explained by the oxidation of sulfide present in the rock.

Oxygen and carbon isotope composition of biogenic carbonates and carbonate of tuff was analyzed from whole rock using samples from Holes 447A, 448, 448A, 449,450 , and 451 (Table 1, Fig. 4). The carbonate-rich portion of Hole 448, has provided the most detailed data, whereas data from the other holes are somewhat limited. The observed scatter of $\delta^{18} \mathrm{O}$ values (from $29.3-31.9 \%$ and $\delta^{13} \mathrm{C}$ (from $0-1.9 \%$ ) are in general typical for unaltered pelagic carbonates. The oxygen isotopic composition of carbonates in most types of tuffs does not differ from that in coccolithic and foraminiferal sediments, but $\delta^{18} \mathrm{O}$ values are slightly low in the carbonates that form an insignificant admixture in tuff in the deep part of Hole $450\left(\mathrm{CO}_{2}\right.$ accounts for 2.6-3.3\%) and in the nannofossil carbonate in volcaniclastic breccia in Hole $447 \mathrm{~A}$ (Layer $3, \mathrm{CO}_{2}=5.8 \%$ ). Three tuff samples sharply differ in isotopic composition of the carbonate material.

Sample $448-17-5,22-24 \mathrm{~cm}$, cored from a thinly bedded tuff in the nannofossil chalk of Unit 2 at a depth of 153 meters, includes a small amount of carbonate $\left(\mathrm{CO}_{2}=1.0 \%\right)$; this carbonate is the most enriched among all the analyses, with heavy carbon and oxygen isotopes $(7.3 \%$ and $33.1 \%$, respectively). In contrast, a negligible amount of the carbonate in a Hole 451 vitric tuff, cored at a depth of 310 meters (Sample 451-34-1; $140-150 \mathrm{~cm}$ ), contains the lightest oxygen and carbon isotopes $(12.1 \%$ and $-2.3 \%$, Table 1$)$. Light carbon also characterizes the tuff sample cored at a 310-meter depth in Hole 448 (Sample 448-34-1, 38-40 cm).

Carbon and oxygen isotopic compositions of calcite intercalations, inclusions, films, and recrystallized cement of volcanogenic rocks (tuffs, and volcaniclastic breccias interbedded with lavas) in Holes 448 and 448A at a 518 to 901.5 meter depth appear in Table 2. Calcite

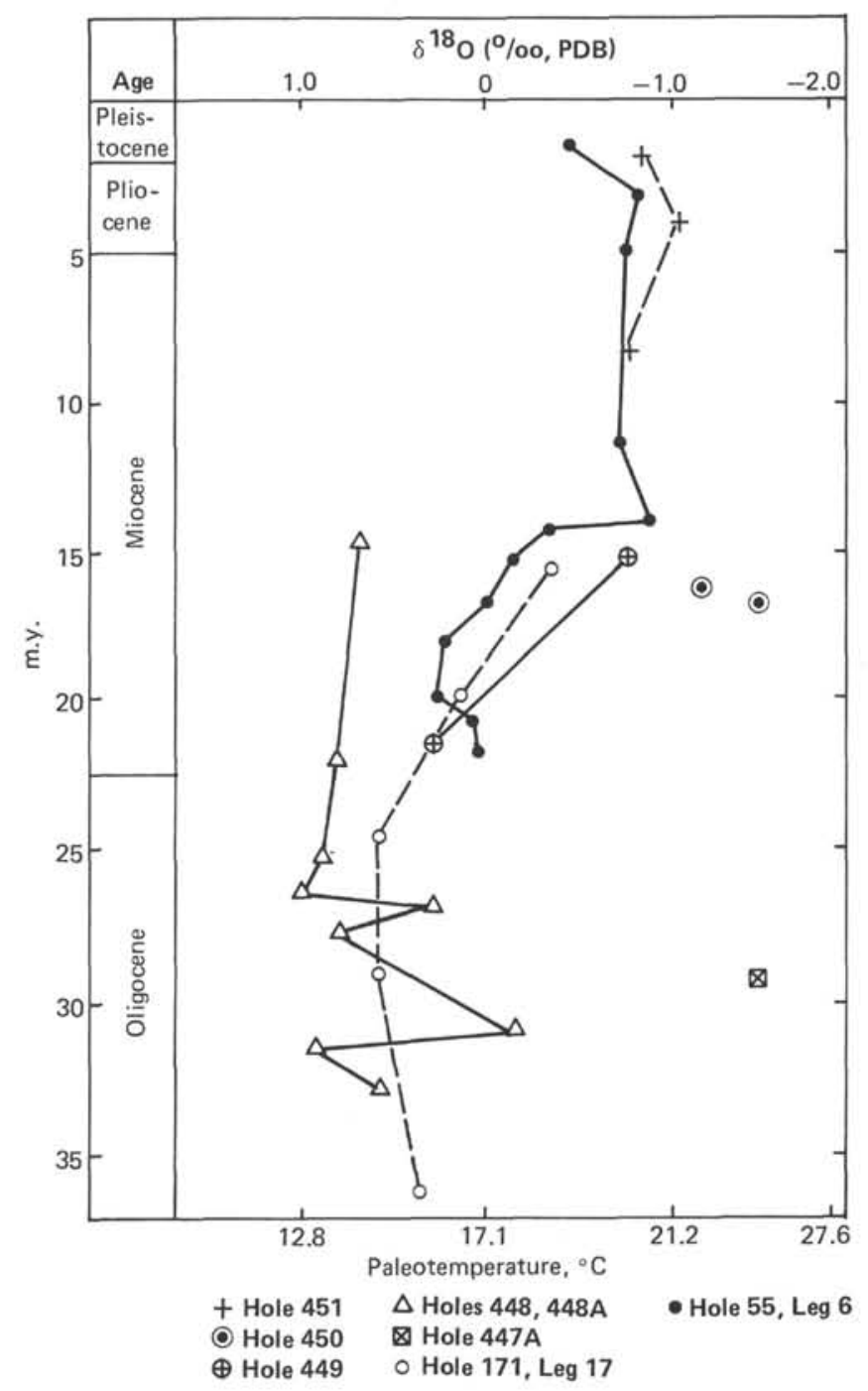

Figure 4. Variations in oxygen isotopic composition of pelagic carbonates in Holes 447A through 451, as well as in Hole 171 (Leg 17) and Hole 55 (Leg 6), in relation to their stratigraphic position.

from rocks from 518 to 712 meters sub-bottom is characterized by $\delta^{13} \mathrm{C}$ and $\delta^{18} \mathrm{O}$ values, which do not differ from those for unaltered pelagic carbonates. The lower part of the hole (736-901.5 m sub-bottom) is identified as a hydrothermal alteration zone, the carbonate is significantly enriched with light oxygen and carbon isotopes in this zone. One of the breccia samples (Hole 448A-56-2, 51-56 cm) containing the smallest amount of the disseminated carbonate material among all analyzed samples $\left(\mathrm{CO}_{2}=0.12 \%\right)$ produced extreme results: $\delta^{13} \mathrm{C}=-49.6 \% ; \delta^{18} \mathrm{O}=-6.1 \%$. That sample (0.5-1.0 $\mathrm{mm}$ fraction) was exposed to heating in a hermetic quartz ampule connected to the LHM-8MD chromatograph. The heating was performed up to $370^{\circ} \mathrm{C}$ for $6 \mathrm{~min}$ in a helium flow. The presence of $\mathrm{CO}_{2}$ $\left(1.0 \pm 0.1 \mathrm{~cm}^{3} / \mathrm{g}\right), \mathrm{CH}_{4}\left(0.05 \pm 0.005 \mathrm{~cm}^{3} / \mathrm{g}\right)$, and lowmolecular hydrocarbons of the methane series $\left(\mathrm{C}_{2}-\mathrm{C}_{3}\right)$ were detected by chromatographic analysis of gas 
Table $2 . \delta^{18} \mathrm{O}, \delta^{13} \mathrm{C}$ of calcite and $\delta^{34} \mathrm{~S}$ of pyrite in volcanic breccia and tuff, Holes $448,448 \mathrm{~A}$.

\begin{tabular}{|c|c|c|c|c|c|c|c|}
\hline \multirow[b]{2}{*}{$\begin{array}{c}\text { Sample } \\
\text { (interval in } \mathrm{cm} \text { ) }\end{array}$} & \multirow{2}{*}{$\begin{array}{l}\text { Depth } \\
\text { in Hole } \\
\text { (m) }\end{array}$} & \multirow[b]{2}{*}{ Lithologic Description } & \multicolumn{3}{|c|}{ Carbonate Derived } & \multirow[b]{2}{*}{$\begin{array}{c}\text { Pyrite } \\
(\%)\end{array}$} & \multirow{2}{*}{$\begin{array}{c}\text { Derived Pyrite } \\
\delta^{34} \mathrm{~S} \\
(\%)\end{array}$} \\
\hline & & & $\begin{array}{l}\mathrm{CO}_{2} \\
(\%)\end{array}$ & $\begin{array}{c}\delta^{13} \mathrm{C} \\
(\%, \mathrm{PDB})\end{array}$ & $\begin{array}{c}\delta^{18} \mathrm{O} \\
(\%, \text { SMOW })\end{array}$ & & \\
\hline $448-58-1,6-14$ & 518.0 & $\begin{array}{l}\text { volcaniclastic breccia } \\
\text { with calcite vein }\end{array}$ & - & 1.1 & 32.3 & - & - \\
\hline $448 \mathrm{~A}-32-2,30-39$ & 709.5 & $\begin{array}{l}\text { volcaniclastic breccia, } \\
\text { calcite impregnated } \\
\text { and veins }\end{array}$ & - & 1.3 & 30.8 & - & - \\
\hline $448 \mathrm{~A}-39-1,68-74$ & 712.5 & $"$ & - & 1.6 & 31.2 & - & - \\
\hline $448 \mathrm{~A}-42-1,0-11$ & 736.0 & $\begin{array}{l}\text { volcaniclastic breccia } \\
\text { with thin coating of } \\
\text { calcite on the wall of } \\
\text { or void }\end{array}$ & 0.26 & -1.3 & 24.1 & 0.008 & -0.4 \\
\hline $448 \mathrm{~A}-42-5,38-45$ & 742.0 & volcaniclastic breccia & 0.19 & -13.6 & 24.7 & 0.030 & 0.8 \\
\hline $448 \mathrm{~A}-43-3,95-100$ & 749.0 & $\begin{array}{l}\text { hydrothermally altered } \\
\text { tuff }\end{array}$ & 0.44 & -8.5 & 25.2 & 0.157 & -21.9 \\
\hline $448 \mathrm{~A}-46-1,57-64$ & 768.0 & $\begin{array}{l}\text { hydrothermally altered } \\
\text { volcaniclastic breccia }\end{array}$ & - & - & - & 0.064 & -3.4 \\
\hline $448 \mathrm{~A}-50-3,85-93$ & 795.5 & " & 0.32 & -9.4 & 29.0 & 0.024 & -5.8 \\
\hline $448 A-56-2,51-56$ & 842.0 & $"$ & 0.12 & -49.6 & -6.1 & 0.225 & -13.1 \\
\hline $448 \mathrm{~A}-58-2,45-51$ & 857.0 & $"$ & 0.35 & -10.8 & 26.6 & 0.050 & -7.1 \\
\hline $448 \mathrm{~A}-64-2,44-47$ & 901.5 & $"$ & 0.35 & -10.7 & 27.5 & 0.324 & -18.8 \\
\hline
\end{tabular}

evolved during heating. These results indicate the necessity of conducting further thorough studies of horizons of hydrothermally altered tuffs and volcaniclastic breccias.

Examination for distribution of sulfides in sediments of Leg 59 holes demonstrated their almost absolute absence. Trace amounts of pyrite $(0.006-0.003 \%)$ in tuff were sometimes found, but concentrations higher than $0.01 \%$ were observed only in four samples. A total absence of the monosulfide forms of sulfur was recorded. The samples with higher sulfide abundances were obtained from Cores 14 and 34 in Hole 451, from Sample 448-26-2, 141-150 cm, and from the basal basaltic volcaniclastic breccia in Hole 447A (Sample 447A-11-1, 11-15 cm). The isotopic composition of pyrite has been determined for three of them; it is characterized by a small enrichment of light sulfur isotope $\left(\delta^{34} \mathrm{~S}=-2.7\right.$ to $-5.8 \%$ ). The amount of sulfur in pyrite disseminated in samples from volcaniclastic breccias interbedded with basalt flows in Hole 448A appeared to be rather high in the zone of the hydrothermal alteration of rocks ( $\mathrm{S}$ in pyrite $=0.024-0.324 \%$ ). The isotopic composition showed significant fluctuations $\left(\delta^{34} \mathrm{~S}=+0.8\right.$ to $\left.-21.9 \%\right)$. In this case the lightest sulfur isotopic compositions were found in samples with the highest pyrite content (Table 2). This relationship is the inverse of that for carbonate carbon, as outlined earlier: the lowest $\delta^{13} \mathrm{C}$ values are typical of samples with the lowest carbonate content. The comparison of isotopic variations of oxygen, carbon, and sulfur in the volcaniclastic breccias in Hole $448 \mathrm{~A}$ is illustrated in Figures 5 and 6.

\section{DISCUSSION}

\section{Interstitial Water}

Numerous studies based on the DSDP data have shown that interstitial water, involved in low-tempera-

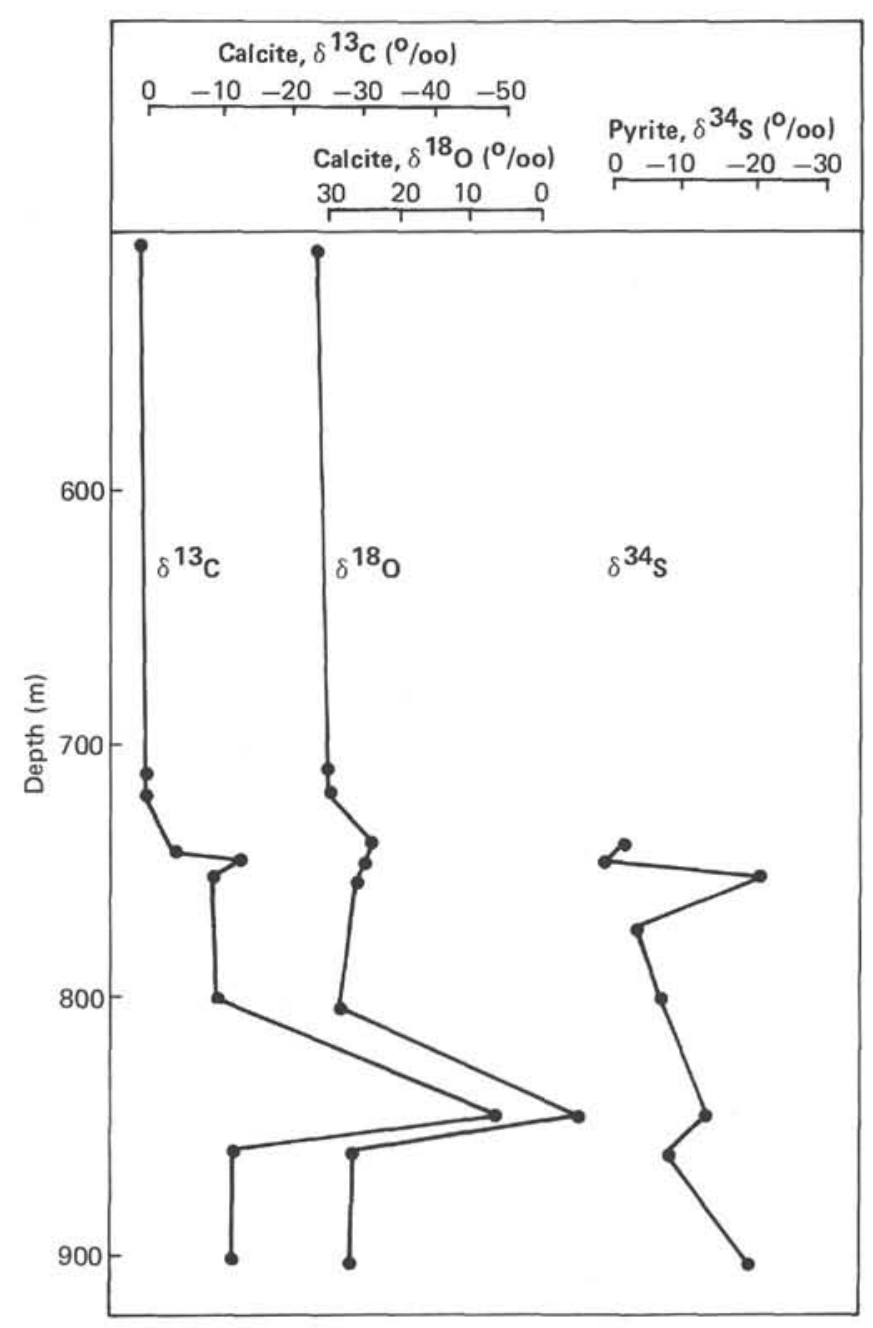

Figure 5. Variations of $\delta^{13} \mathrm{C}$ and $\delta^{18} \mathrm{O}$ values for calcite and $\delta^{34} \mathrm{~S}$ value for pyrite in Holes 448 and $448 \mathrm{~A}$. 


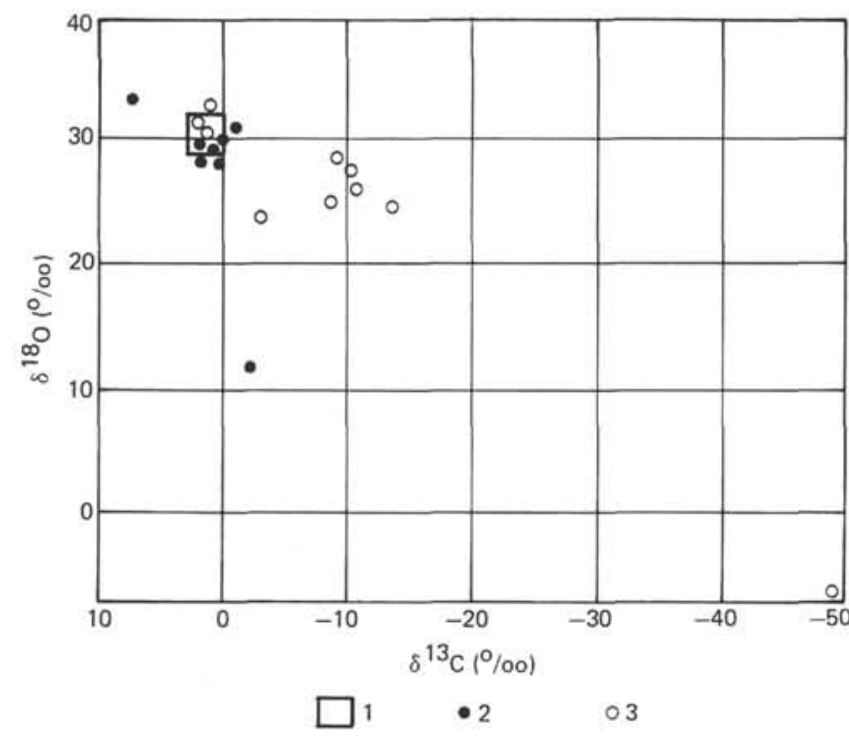

Figure 6. Carbon and oxygen isotopic composition of the carbonate material of volcanogenic-sedimentary rocks, Holes 447 through 451. ( 1 = biogenic carbonates in Holes $447-451 ; 2=$ tuff variously enriched with carbonate $\left[\mathrm{CO}_{2}\right.$ content is $5-6 \%$ or less]; $3=$ intercalated and mottled calcite in volcaniclastic breccias in Holes 448 and 448A.)

ture interaction with rocks, is poor in heavy oxygen isotope as compared with the initial ocean water. The light isotopic water results from the formation of authigenic silicates whose oxygen is $10 \%$ to $30 \%$ o heavier than that of volcanic rocks (Savin and Epstein, 1970; Garlic and Dymond, 1970; Muehlenbachs and Clayton, 1972). According to Lawrence et al. (1975) $\delta^{18} \mathrm{O}$ values for interstitial water sampled from volcanogenicsedimentary rocks in holes in the central part of the Caribbean Sea and in the eastern part of the Pacific decrease regularly down-section to $-3 \%$. In this case, secondary alteration of the rocks is related to variations of oxygen isotopic composition of pore waters.

The variations of oxygen isotopic composition of interstitial water observed in parts of the Leg 59 holes are generally quite comparable with these cited data (Table 1, Fig. 1). In our case, too, the lowest ${ }^{18} \mathrm{O}$ values in water were observed in the deepest horizons of the continuous section of chemically uniform andesitic tuff. This fact suggests that in this case the variations of oxygen isotopic composition of interstitial water also controlled by the interaction of volcanogenic rocks and seawater. This possibility is also supported by the synchronous variations of ${ }^{18} \mathrm{O}$ of interstitial water and its chemical composition in the tuff column of Hole 450 (Fig. 2).

At the same time, the water that was moderately enriched in the heavy oxygen isotope was observed higher in the section, as mentioned previously. It should be noted, however, that this zone was formed with rocks of different lithologic character in different holes: mainly carbonate oozes in Holes 448 and 451 but also pelagic clay in Holes 449 and 450.

Recrystallization of biogenic carbonate and biogenic silica during lithification of sediments could be the pro- cess that was responsible for the increase in ${ }^{18} \mathrm{O}$ isotope concentration in water, as suggested by Lawrence et al. (1975). A comparison of a degree of the carbonate recrystallization (based on lithologic descriptions) with oxygen isotopic composition of interstitial water does not indicate any definite relationships. This is no reason, however, to dismiss entirely the possibility of the occurrence of this process, although there are no quantitative estimates of a degree of lithification and recrystallization of rocks. The concentration of lighter carbonate oxygen during recrystallization and the corresponding occurrence of heavy oxygen in interstitial water that is in equilibrium with these carbonates may be supported by the aforementioned lightness of the oxygen isotopic composition of the carbonate material in Holes 447A and 450 , compared with nonlithified carbonate ooze of the same age in adjacent holes (Fig. 4).

Another process that can result in a heavier oxygen isotopic composition is sedimentation of ferric oxides that have a lighter oxygen isotopic composition at low temperature than does the water in equilibrium with them (Taylor, 1974; Friedman and O'Neil, 1977). Although direct experimental data have been obtained only for magnetite, we may assume that the same conclusion is valid for ferric hydroxides. Some indirect data also confirm this conclusion; Dymond et al. (1973) demonstrated from their own studies and reported data that the higher content of ferric and manganous hydroxide forms controls the decrease of $\delta^{18} \mathrm{O}$ of sediments, whereas the increase of smectite in sediments results in higher $\delta^{18} \mathrm{O}$ values. The differences in isotopic composition of smectite and water become smaller with the increase of the iron content of smectite (Lawrence and Taylor, 1972). Montmorillonite, with $7 \%$ to $8 \%$ of $\mathrm{Fe}_{2} \mathrm{O}_{3}$, is poorer in ${ }^{18} \mathrm{O}$ by about $3 \%$ than are various low-ferric subspecies. The inverse must be true for water in equilibrium with the system. The phase-shift analysis of iron forms has not been made for the Leg 59 samples; thus we use the $\mathrm{Fe}^{+3} / \mathrm{Al}$ ratio as a rough estimate of the relative content of the hydroxide form of iron in pelagic clay (Boström, 1973; Piper, 1973; Strakhov, 1976). Changes of this ratio in sediments with high ferric-oxide contents (Holes 447, 449) inherent in intra-arc-basin deposits are well correlated with fluctuations of $\delta^{18} \mathrm{O}$ values for interstitial water of these sediments (Fig. 3; the correlation coefficient $r$ for $\delta^{18} \mathrm{O}_{\mathrm{H}_{2} \mathrm{O}}$ versus $\mathrm{Fe}+3 / \mathrm{Al}$ $=0.90$ ). Also, results of the examination of interstitial water from carbonate samples generally do not contradict this dependence. Sample 448-6-3, 140-150 cm, which at first seems to be an exception, has been cored near a lens consisting of $60 \%$ amorphous ferric hydroxides, according to the lithologic description of Horizon $448-6-3,87 \mathrm{~cm}$. That is why the interstitial water richest in heavy oxygen $\left(\delta^{18} \mathrm{O}=0.5 \%\right.$ ) in this area seems to confirm this relationship.

Thus we may conclude from the data on the oxygen isotopic composition of interstitial water in the volcanogenic sediments of the southern part of the Philippine Sea that the isotopic and chemical composition of the water is controlled by its low-temperature interaction with volcanogenic rock or with the admixture of vol- 
canic glass in sediments. This process is active at different intensities throughout the volcanogenic-sedimentary rocks beginning with the first meters below the seafloor, where interstitial water is already poor in ${ }^{18} \mathrm{O}$. However, this process is most pronounced in the continuous volcanic tuff of Hole 450, where the deficit of the heavy oxygen isotope appears to be highest. Based on our data and other reported data, we think that this natural process is affected by a second natural process within the sedimentary part of the section. In our opinion, the second process is of more local significance and controls the inverse character of the general behavior of $\delta^{18} \mathrm{O}$ values for interstitial water. This second process is the authigenic mineralization that occurs in the sedimentary material. Recrystallization of carbonate and silica frameworks may turn out to be one of the factors that induces the increase in the heavy oxygen content in sedimentary interstitial water. A possible consequence of this process is well known (Lawrence et al., 1975). Another possible reason for this effect is the formation of ferric oxides and hydroxides, as explained previously in this chapter. The isotopic impact of numerous reactions accompanying the alteration of silicate mineral associations with increasing depth (Kossovskaya and Shutov, 1975) remains unclear, however.

The constant sulfur isotopic composition of sulfates in interstitial water and the negligible fluctuations of the sulfate concentrations around the mean value for ocean water suggest that sulfate reduction and the processes that affect supply and loss of sulfur did not occur or had a negligible effect from the time of burial. This is also confirmed by the absence or trace amounts of sulfides in sediments.

\section{Biogenic Carbonates}

We attempted to estimate the general temperature trends in the paleobasins of the Philippine Sea region, although the carbon and oxygen isotopic compositions were analyzed in the total carbonate, and no special paleotemperature studies were undertaken. The oxygen isotopic composition of the biogenic carbonates relative to their age is presented in Figure 4, where paleotemperatures derived (after Epstein et al., 1953; Craig, 1965) from contemporaneous oxygen composition of initial seawater are also shown. Leg 59 data correlate well with results of paleotemperature investigations of the same region and the adjacent part of the Pacific (Fischer, Heezen, et al., 1971; Winterer, Ewing, et al., 1973; Douglas and Savin, 1973). Only three samples mentioned earlier, including the recrystallized carbonate portion, proved to be lighter, thus conditions of formation may be misrepresented (Holes 447A, 450).

\section{Calcite Intercalations, Disseminated Carbonates and Pyrite in Tuff, and Volcaniclastic Breccias Interbedded with Basalt Flows (Holes 448, 448A); Hydrothermally Altered Rocks}

In many cases isotopic compositions of calcite intercalations in volcanogenic, volcanogenic-sedimentary, and igneous rocks cored from DSDP holes originate from low-temperature processes of the chemical and isotopic exchange between rocks and interstitial water. At the same time, some isotopic data indicate that certain solutions, probably different in composition from ocean water, participated in the secondary transformations of these rocks. In this context we shall mention data for (1) the carbon isotopic composition of inclusions in the Mid-Atlantic Ridge basalts: $\delta^{18} \mathrm{C}=$ $-15 \%$ to $-24 \%$ (Pineau and Javoy, 1976); (2) isotopically light sulfides detected in basalts of the MidAtlantic Ridge and some other rift zones: $\delta^{34} \mathrm{~S}$ up to $-33.4 \%$ (Krouse et al., 1977; Grinenko et al., 1978); and finally (3) calcites significantly richer in ${ }^{12} \mathrm{C}$ in hydrothermally altered deep-sea sediments (Anderson and Lawrence, 1976).

Secondary calcite from the upper zone of tuff and volcaniclastic breccias (interbedded with basalts) has carbon and oxygen isotopic compositions similar to those of pelagic carbonates (Table 2); this proves that seawater is the solution in which calcite was precipitated. In this case, calculated temperatures of the formation of these intercalations fall within $5.3^{\circ} \mathrm{C}$ and $12.1^{\circ} \mathrm{C}$ (here and in the following material, temperatures have been calculated after O'Neil et al., 1969). It is highly probable, however, that intercalated calcites were formed in interstitial water already transformed by its interaction with rocks. If $\delta^{18} \mathrm{O}$ for initial water is taken as $-1.5 \%$ (interstitial water of the tuff in Hole 450 ), the equilibrium formative temperature for these intercalations amounts to $0.1^{\circ} \mathrm{C}$ to $6.1^{\circ} \mathrm{C}$. Temperature conditions for the formation of calcites of the upper zone of volcaniclastic breccias (Holes 448, 448A, 518-712 m sub-bottom depth) are practically equal to seafloor temperatures, as our estimates show; this fact indicates that the formation of veins has resulted from the lowtemperature water-rock interaction.

However, the volcaniclastic breccias and tuffs cored deeper than 736 meters contain carbonates that are much richer in light oxygen, which may be a response to the hydrothermal alteration of these rocks (see the lithologic description in Table 2 as well as in the site chapter, this volume). It is in that part of the section that we observe a significant amount of pyrite as well as a considerable lightness of its isotopic composition $\left(\delta^{34} \mathrm{~S}\right.$ up to $-21.9 \%$, Table 2 ). An irregularity in the ${ }^{12} \mathrm{C}$ values is also typical for the same depths: the $\delta^{13} \mathrm{C}$ of calcite fluctuates around $-10 \%$ below the 736 meter depth. Such simultaneous lightness of the isotopic composition for various elements within the same-depth interval of Hole 448A suggests a genetic interrelationship between these effects.

One of the questions that should be solved using the observed isotopic composition data is: To what extent are the high-temperature (hydrothermal) rock-alteration processes responsible for the genesis of the studied minerals and their isotopic composition?

Data on the equilibrium formation temperatures for calcite in the upper zone of basalt flows and volcaniclastic breccias as well as for carbonates in lower zones are presented in Table 3 for extreme cases: initial water corresponding to the ocean standard and water transformed to $\delta^{18} \mathrm{O}=-1.5 \%$ owing to its interaction 
Table 3. Equilibrium temperatures for precipitation of calcites and carbon isotopic composition of initial $\mathrm{CO}_{2}$ in tuffs and volcaniclastic breccias in Holes 451, 448, and 448A.

\begin{tabular}{|c|c|c|c|c|}
\hline \multirow[b]{2}{*}{$\begin{array}{c}\text { Sample } \\
\text { (interval in } \mathrm{cm} \text { ) }\end{array}$} & \multicolumn{2}{|c|}{$T^{\circ} \mathrm{C}^{\mathrm{a}}$} & \multicolumn{2}{|c|}{$\delta^{13} \mathrm{C}$ of $\mathrm{CO}_{2}{ }^{\mathrm{b}}(\%)$} \\
\hline & $\delta^{18} \mathrm{O}_{\mathrm{H}_{2} \mathrm{O}_{\text {init. }}}=-1.5$ & $\delta^{18} \mathrm{O}_{\mathrm{H}_{2} \text { Oinit. }}=0.0$ & $\delta^{18} \mathrm{O}_{\mathrm{H}_{2} \mathrm{O} \text { init. }}=-1.5$ & $\delta^{18} \mathrm{O}_{\mathrm{H}_{2} \mathrm{O} \text { init. }}=0.0$ \\
\hline $451-54-2,0-8$ & 15.5 & 22.2 & -12.0 & -11.2 \\
\hline $448-58-1,6-14$ & 0.4 & 5.3 & -14.1 & -13.5 \\
\hline $448 \mathrm{~A}-38-2,30-39$ & 6.1 & 12.1 & -13.6 & -12.9 \\
\hline $448 \mathrm{~A}-39-1,68-74$ & 4.5 & 10.5 & -14.0 & -13.4 \\
\hline $448 \mathrm{~A}-42-1,0-11$ & 36.7 & 45.0 & -11.9 & -11.1 \\
\hline $448 A-42-5,38-45$ & 33.5 & 41.6 & -22.9 & -22.1 \\
\hline $448 \mathrm{~A}-43-3,95-100$ & 31.0 & 38.8 & -18.0 & -17.7 \\
\hline $448 \mathrm{~A}-50-3,85-93$ & 13.4 & 20.0 & -20.8 & -20.1 \\
\hline $448 A-56-2,51-56$ & $18.5^{\mathrm{c}}$ & $23.9^{\mathrm{c}}$ & -60.5 & -59.8 \\
\hline $448 \mathrm{~A}-58-2,45-51$ & 24.1 & 31.5 & -21.0 & -20.2 \\
\hline $448 \mathrm{~A}-64-2,44-47$ & 20.0 & 27.0 & -21.4 & -20.6 \\
\hline
\end{tabular}

a Equilibrium temperatures are calculated after O'Neil et al., 1969.

b Calculation of $\delta^{13} \mathrm{C}$ in equilibrium with $\mathrm{CO}_{2}$ (after Bottinga, 1969).

c Calculated temperatures of calcite precipitation for all examined horizons in tuffs and volcaniclastic breccias.

with rocks. According to the results obtained, the temperature range for the formation of carbonate intercalations and inclusions in this zone is estimated to be $13.4^{\circ} \mathrm{C}$ to $45.0^{\circ} \mathrm{C}$ and is too low to be considered the result of a hydrothermal process. So it may be supposed that in this case seawater is only slightly heated; all calculated equilibrium temperatures appear to be lower or approximately equal to those corresponding to the geothermal gradient of $4^{\circ} \mathrm{C}$ to $5^{\circ} \mathrm{C} / 100$ meters (Lawrence et al., 1975).

Temperatures of the lower "hydrothermally altered" part of Hole 448A are only slightly higher than those of upper horizons. It is doubtful that higher temperatures of solutions are responsible for differences in mineralization processes in the upper part or the lower part of the hole. This conclusion is also confirmed by the examination of Sample 448A-56-2, 51-56 cm, which suggests that calcite has precipitated from interstitial water: its oxygen is highly enriched in the light isotope, although additional tests and more extensive materials are necessary. If we assume that the temperature of the precipitation of that calcite is equal to the average temperature calculated for carbonates of the "hydrothermally altered" volcaniclastic breccias in Hole 448A, then the $\delta^{18} \mathrm{O}$ value of water in equilibrium with calcite is close to that of continental meteoric water. It is noteworthy that the oxygen isotopic composition of carbonate from Hole 451, from the younger West Mariana island arc, also may be interpreted in two ways. Here an equilibrium formation temperature of calcite in contact with unaltered ocean water (for Sample 451-34-1, 140-150 $\mathrm{cm})$ is $150^{\circ} \mathrm{C}$. This suggests that in this case a true hydrothermal temperature was reached. However, hydrothermal alterations have not been found in this sample. If we assume that the carbonate formation temperatures of this horizon do not significantly differ from those found for carbonates of Hole 448A (confirmed by a sample from Hole 451 cored deeper than this horizon-Sample 451-54-2, 0-8 cm-see Table 3), we can also show in this case that water of circulating solutions is significantly richer in light oxygen. It should be mentioned that lignite was detected in the lower part of Hole 451 ; this phenomenon probably required a subaerial formation environment.

From a summary of these results, we may conclude that the deepest horizons of samples from island arcs were probably formed at comparatively shallow depths or even partially subaerially. Thus we may suppose that favorable conditions for oxidation-reduction reactions associated with organic material occurred between basalt eruptions. It has already been noted that the carbon isotopic composition of carbonates from deep horizons in volcaniclastic breccias is considerably richer in ${ }^{12} \mathrm{C}$ (about $-10 \%$ ). An extreme $\delta^{13} \mathrm{C}$ value for Sample 448A-52-2, 51-56 cm testifies to the fact that oxidation of the organic material accounts for the formation of carbonic acid, and the level of accumulation of light carbon shows that it could be identified only as biochemical methane. The isotopic composition of carbon in equilibrium with $\mathrm{CO}_{2}$ at other horizons in the deeper part of the section of Hole 448A (Table 3 ) confirms that organic carbon was involved in the calcite formation. A sufficiently high correlation between the carbonate content in the rock and its carbon isotopic composition ( $r$ for $\mathrm{CO}_{2}$ versus $\delta^{13} \mathrm{C}=0.7$ ) suggests that bicarbonate, formed through organic material oxidation, and common seawater bicarbonate were mixed during formation of the carbonate.

Sulfides that are richer in light sulfur and have significant fluctuations of the $\delta^{34} \mathrm{~S}$ values may serve as an additional proof of the previous statement. However, similar sulfur isotopic compositions sometimes have been detected in intercalations and inclusions of sulfides within basalts (Smitheringale and Jensen, 1963; Krouse et al., 1977; Grinenko et al., 1978). This phenomenon requires speculation about possible sources for the formation of sulfides with such isotopic composition. 
Disseminated blebs and veins of sulfide of this type have three hypothetical origins: (1) interaction of seawater and basalts; (2) precipitation from hydrothermal solutions with changing $p \mathrm{H}, f_{\mathrm{O}_{2}}$, and $T$ parameters; and (3) exchange of sedimentary sulfides with circulating solutions.

In the first case, partial reduction of seawater sulfate with the subsequent formation of sulfides can occur as a result of the interaction between seawater and hot basalts. Such interaction, however, should be expected at a temperature not lower than $200^{\circ} \mathrm{C}$. Because the separation factor for the chemical reduction of sulfates at $200^{\circ} \mathrm{C}$ is equal to 1.014 (Grinenko et al., 1969) and does not exceed 1.022 even at $25^{\circ} \mathrm{C}$ (Harrison and Thode, 1957), the formation of sulfides with very low $\delta^{34} \mathrm{~S}$ values cannot be considered a consequence of the kinetic effect that accompanies the reduction of seawater sulfates of $\delta^{34}=20 \%$. The partial reduction of sea sulfates followed by a stable isotopic exchange between sulfides and sulfates is also unsatisfactory, because this process requires temperatures lower than $200^{\circ} \mathrm{C}$ for sulfides of $\delta^{34} \mathrm{~S}=-21 \%$; the sulfatereduction process and the possibility of stable isotopic equilibrium seem improbable at such temperatures.

Sulfides that are supposed to be formed from hydrothermal solutions (with initial sulfur of $\delta^{34} \mathrm{~S}$ close to that of initial basalts- $\left(\delta^{34} \mathrm{~S}=+1 \%\right.$ [ [Kaneshira et al., 1973; Grinenko et al., 1975]) as a result of the change of physical-chemical parameters of the solutions, can have low $\delta^{34} \mathrm{~S}$ values only if the sulfate form of sulfur is predominant. In the tuff and volcaniclastic breccias in Hole 448A, the lowest $\delta^{34} \mathrm{~S}$ value was found in rocks with the highest sulfide content ( $r$ for $\mathrm{S}_{\text {pyrite }}$ versus $\delta^{34} \mathrm{~S}=-0.8$ ). Therefore this model will not contradict the data only if the change in solution parameters and the precipitation of sulfides are separated in time and space.

The simplest model for the formation of the observed sulfides (Table 2) is that of bacterial reduction of seawater sulfate. In this case, the nonuniform isotopic composition of sulfur from sulfides is associated with various degrees of sulfate reduction. Sulfate reduction occurs simultaneously with the oxidation of the organic material followed by the generation of carbonic acid that has light carbon.

We think that the latter model more closely fits all the isotopic data discussed above. It also does not contradict the data derived from organic-geochemical examination of Hole 448, which suggest periods of high organic productivity after eruptions (see the Site 448 report, this volume).

In summary, these data on the isotopic composition of carbonate and sulfide inclusions and intercalations in interbedded basalts, tuffs, and volcaniclastic breccias lead us to some preliminary conclusions:

1) The formation of intercalations and inclusions of carbonates in the shallower depths (518-712 m) resulted from the low-temperature interaction between water and rocks.
2) The formative temperature for carbonate at the deeper parts (deeper than $736 \mathrm{~m}$ ) also seems to be rather low (no higher than $45^{\circ} \mathrm{C}$ ) and does not exceed values for a geothermal gradient of 4 to $5^{\circ} \mathrm{C} / 100$ meters.

3) The isotopic composition of carbonates and sulfides is largely determined by the participation of biogenic processes in mineral formation.

4) The deepest parts of Hole 448 and perhaps of Hole 451 could have been formed in more shallow seas, possibly in subaerial conditions in some cases.

\section{ACKNOWLEDGMENTS}

The authors are grateful to A. B. Ronov, E. M. Galimov, and A. Ya. Sharaskin for their critical reading of the manuscript.

\section{REFERENCES}

Anderson, T. F., and Lawrence, G. R., 1976. Stable isotope investigations of sediments, basalts, and authigenic phases from Leg 35 cores. In Hollister, C. D., Craddock, C., et al., Init. Repts. DSDP, 35: Washington (U.S. Govt. Printing Office), 497-506.

Boström, K., 1973. The origin and fate of ferromanganoan active ridge sediments. Stockholm Contrib. Geol., 27:149-243.

Bottinga, Y., 1969. Calculated fractionation factors for carbon and hydrogen isotope exchange in the system calcite-carbon dioxidegraphite-methane-hydrogen-water vapor. Geochim. Cosmochim. Acta, 33:49-64.

Craig, H., 1965. The measurement of oxygen isotope paleotemperatures. Stable Isotopes in Oceanographic Studies and Paleotemperatures, Proc. Spoleto Conf. Nucl. Geol., pp. 161-182.

Douglas, R. G., and Savin, S. M., 1973. Oxygen and carbon isotope analyses of Cretaceous and Tertiary foraminifera from the central North Pacific. In Winterer, E. L., Ewing, J. I., et al., Init. Repts. DSDP, 17: Washington (U.S. Govt. Printing Office), 591-606.

Dymond, J., Corliss, J., Heath, G., et al. 1973. Genesis of iron-rich sediments from the East Pacific Rise. Bull. Geol. Soc. Am., $84: 3355-3372$.

Epstein, S., Buchsbaum, R., Lowenstam, H. A., et al., 1953. Revised carbonate-water isotopic temperature scale. Bull. Geol. Soc. Am., 64:1315-1326.

Fischer, A. G., Heezen, B. C., et al., 1971. Init. Repts. DSDP, 6: Washington (U.S. Govt. Printing Office).

Friedman, J., and O'Neil, G. R. O. (Eds.), 1977. Data of Geochemistry, 6th Edition: Washington (USGS).

Garlic, G. D., and Dymond, G. R., 1970. Oxygen isotope exchange between volcanic materials and ocean water. Bull. Geol. Soc. Am., $81: 2137-2142$.

Grinenko, V. A., Dmitriyev, L. V., Migdisov, A. A., et al., 1975. Sulfur content and isotopic composition in magmatic and metamorphic rocks of mid-oceanic ridges. Geokhimiya, 2:199-206.

Grinenko, V. A., Grinenko, L. N., and Zagryazhskaya, G. D., 1969. Kinetic isotopic effect in high-temperature reduction of sulfates. Geokhimiya, 4:484-491.

Grinenko, V. A., Migdisov, A. A., Girin, Yu. P., et al., 1978. On the sources of sulfur in bedrocks and sediments of active zones of the south-eastern part of the Pacific. Proc. 7th National Symposium on Stable Isotopes in Geochemistry: Moscow.

Harrison, A. G., and Thode, H. G., 1957. The kinetic isotope effect in the chemical reduction of sulphate. Trans. Faraday Soc., 53: 1648-1651.

Kaneshira, K., Yni, S., Sakai, H., et al., 1973. Sulphide globulos and sulphur isotope ratios in the abyssal tholeite from the MidAtlantic Ridge near $30^{\circ} \mathrm{N}$ latitude. Geochem. J., 7:89-96.

Kossovskaya, A. G., and Shutov, V. D., 1975. Mineral indicators of geotectonic types of regional epigenesis and of its conjugation with metamorphism at continents and oceans. In Kossovskaya, A. G. (Ed.), Crystallochemistry of Minerals and Geological Problems: Moscow (Nauka), 19-34.

Krouse, H. R., Brown, H. M., and Farquharson, R. B., 1977. Sulfur isotopic composition in DSDP Leg 37 cores. In Aumento, F., Mel- 
son, W. G., et al., Init. Repts. DSDP, 37: Washington (U.S. Govt. Printing Office), 621-624.

Lawrence, G. R., Gieskes, G. M., and Broecker, W. S., 1975. Oxygen isotope and cation composition of DSDP pore water and the alteration of Layer 2 basalts. Earth Planet. Sci. Lett., 27:1-10.

Lawrence, G. R., and Taylor, H. R., 1972. Hydrogen and oxygen isotope systematic in weathering profiles. Geochim. Cosmochim. Acta, 36:1377-1393.

Muehlenbachs, K., and Clayton, R., 1972. Oxygen isotope studies of fresh and weathered submarine basalts. Can. J. Earth Sci., 9:172.

O'Neil, G. R., Clayton, R. N., and Mayeda, T. K., 1969. Oxygen isotope fractionation in divalent metal carbonates. J. Chemical Physics, 51:5547-5558.

Pineau, F., and Javoy, M., 1976. Etude de la composition isotopiqe des inclusions fluides contennes dans les "popping rocks" de la Ride Medio-Atlantique. 4 éme Réunion Annuelle Science Terre: Paris.

Piper, D. Z., 1973. Origin of metalliferous sediments from the East Pacific Rise. Earth Planet. Sci. Lett., 19:75-82.
Savin, S. M., and Epstein, S., 1970. The oxygen and hydrogen isotope geochemistry of ocean sediments and shales. Geochim. Cosmochim. Acta, 34:43-63.

Smitheringale, G., and Jensen, M. L., 1963. Sulfur isotopic composition of the Triassic igneous rocks of eastern United States. Geochim. Cosmochim. Acta, 27:1183-1207.

Strakhov, N. M., 1976. Geochemical Problems of Contemporaneous Oceanic Lithogenesis: Moscow (Nauka).

Taylor, H. P., 1974. The application of oxygen and hydrogen isotope studies to problems of hydrothermal alteration and ore deposition. Econ. Geol., 69:843-883.

Teys, R. V., and Naydin, D. P., 1973. Paleothermometry and Oxygen Isotopic Composition of Organic Carbonates: Moscow (Nauka).

Ustinov, V. I., and Grinenko, V. A., 1965. A Precision MassSpectrometric Method for the Determination of Sulfur Isotopic Composition: Moscow (Nauka).

Volkov, I. I., and Zhabina, N. N., 1977. Determination of pyritic sulfur by means of metallic chromium and chromic salt solution (II). In Ostroumov, E. A. (Ed.), Chemical Analysis of Sea Sediments: Moscow (Nauka), pp. 5-14.

Winterer, E. L., Ewing, J. I., et al., 1973. Init. Repts. DSDP, 17: Washington (U.S. Govt. Printing Office). 